\title{
Biological and physiological effects of pyriproxyfen insecticide and amino acid glycine on silkworm, Bombyx mori L
}

\author{
Mahmoud S. I. Saad ${ }^{1 *}$ (D, Walaa M. M. Helaly ${ }^{2}$ and El-Sayed A. El-Sheikh ${ }^{2}$
}

\begin{abstract}
Background: Natural silk is one of the best yarns that attract large number of users and become a very important industry. Mulberry leaves is a natural food of silkworm, therefore scientists have recently incorporated methods for increasing production of silk. These methods use the insect growth regulators (IGRs) or similar peptide hormones and amino acids to prolong the last larval instar to obtain large cocoon and high quality silk recipes.

Results: The present investigation was carried during the spring (season 2018) to evaluate the effect of growth regulator pyriproxyfen at concentrations 1, 10, and $100 \mu \mathrm{g} /$ larva on Bombyx mori L., as well as the effect of amino acid glycine $1 \%$ concentration solely or in combination with pyriproxyfen at the fifth day of fifth larval instar. Feeding fifth instar larvae of B. mori on mulberry leaves dipped in glycine $1 \%$ resulted in a significant increase in the weight of mature larvae and shorter larval duration, recording $5.12 \mathrm{~g}$ and 9.00 days, respectively. Meanwhile, the highest significant pupal weight $(1.277 \mathrm{~g})$ was attained when larvae were treated topically with pyriproxyfen at $10 \mu \mathrm{g} /$ larva in the fifth day in combined with glycine $1 \%$. Regarding technological parameters, larvae which were topically treated with pyriproxyfen at $10 \mu \mathrm{g} /$ larva at fifth day and fed on mulberry leaves immersed in $1 \%$ glycine possessed the highest means of cocoon weight, cocoon shell weight, cocoon shell ratio, silk filament weight, and size over other treatments. The total protein and ALT were attained a higher mean recording $78.433 \mathrm{mg} / \mathrm{ml}$ and $51.053 \mathrm{mg} / \mathrm{ml}$ for control larvae, successively. Meanwhile, it showed the lowest values for total carbohydrate and AST.

Conclusion: The study showed that pyriproxyfen prolonged the fifth larval instar, while the use of glycine led to shortening the fifth larvae instar. Exposure to mixture of IGR and glycine, however, enhanced the parameters of silk compared with control.
\end{abstract}

Keywords: Bombyx mori, Pyriproxyfen, Glycine, Biology, Technology, Silk filament

\section{Introduction}

uvenile hormones (JHs) are secreted by a pair of endocrine glands behind the brain called the corpora allata. They are important in several physiological processes such as reproduction and development as the repetition of larval stage due to existing of $\mathrm{JH}$ and switching the final larval instar into pupal stage as a result of decline in JH level (Riddiford 1994; Kremen and Nijhout 1998). Synthetic analogs of $\mathrm{JH}$ are used as insecticides for preventing the larvae from developing into adults (Kotikal and Devaiah

\footnotetext{
*Correspondence: mshsaad@gmail.com

${ }^{1}$ Plant Protection Research Institute, Agricultural Research Center, Dokki

12622, Egypt

Full list of author information is available at the end of the article
}

1986). In contrast, juvenile and molting hormones and their analogs (juvenoids and ecdysoids) have been found to be useful in insect culture such as sericulture industry when used judiciously.

$\mathrm{JH}$ analogues have been tested in Bombyx mori as insect growth regulators (IGRs) in order to increase silk production (Chowdhary et al. 1990; Cappellozza et al. 1997) when applied in appropriate rates for promoting the extension of the larval period during insect feeds. Earlier studies with $\mathrm{JH}$ analogues on $B$. mori were accomplished through topical applications (Akai et al. 1971, 1973; Murakoshi et al. 1972). Later, researchers looked for the practical application of these hormones in the sericulture (José et al. 2002 
and Yang et al. 2017). Low concentrations of IGRs (chlorfluazuron, Lufenuron, and hexaflumuron) found to have high significant effects on the productivity characters of the Chinese silkworm hybrid (Saad 2009; Biswaranjan and Kallyani 2011)

Early JHAs are based on the terpenoid structure of $\mathrm{JH}$ such as methoprene and hydroprene, which lack the epoxide function present in $\mathrm{JH}$. While, more recent synthesized highly active compounds of JHAs are appearing less similar with $\mathrm{JH}$ such as fenoxycarb and pyriproxyfen (Aribi et al. 2006). Accordingly, experiments carried out in this study aimed to investigate the effect of JHA pyriproxyfen on production of silk on $B$. mori. The fifth instar larvae of $B$. mori were exposed into three concentrations of pyriproxyfen individually at different period. In addition, the binary effect of pyriproxyfen and glycine amino acid was investigated on fifth larval instar development and cocoon production with relation to effect on some physiological parameters.

\section{Materials and methods}

The present study was carried out during the spring (season 2018) to investigate the effect of exposure of $B$. mori to pyriproxyfen, as well as effect of glycine amino acid individually or in combination with pyriproxyfen at fifth day of fifth larval instar.

\section{Insect source and rearing}

Eggs of mulberry silkworm B. mori ( $\mathrm{H} 1 * \mathrm{KK} * \mathrm{G} 2 * \mathrm{~V} 2)$ were obtained from Sericulture Research Department of Plant Protection Research Institute, ARC and maintained in rearing room of silkworm under laboratory conditions ( $28 \pm 2{ }^{\circ} \mathrm{C}$ and $70 \pm 5 \% \mathrm{RH}$ ) according to the technique of Krishnaswami (1978). Mulberry leaves (Balady variety) were collected twice daily, i.e., at 8 am and $4 \mathrm{pm}$, then washed and left to dry as needed under room conditions. Larvae were offered mulberry leaves four times/day in plastic trays $(42 \times 30 \times 10 \mathrm{~cm})$ with approximate number of 30 larvae/tray. Rearing trays, tools, and rearing room were disinfected 1-week prior the onset of the experiment using formalin (3\% concentration) ( $40 \%$ formaldehyde). The larval bed was cleaned daily using cleaning net for removing the remained dried food and feces. Chicken egg cartons plates were used as montages for cocoon spinning (Zannoon and Omra 1994).

\section{Insecticide and amino acid tested}

The insecticide used in this study is related to IGR insecticides. Technical grade $95 \%$ of pyriproxyfen was obtained from the local company of El-Helb group, Damietta, Egypt.

Glycine $\left(\mathrm{C}_{2} \mathrm{H}_{5} \mathrm{NO}_{2}\right)$, or glycocoll or N-glycine, is Nsubstituted p-aminophenol product of sigma co. as powder package, molecular weight: $75.07 \mathrm{~g} / \mathrm{mol}$.

\section{Experiment design and larval treatment}

Larvae under investigation were divided into four main groups. When reared larvae of B. mori reached the beginning of fifth instar, groups of larvae were randomly separated in the previously mentioned plastic trays and offered normal food until second day (group 1), fifth day (group II and III), and eighth day (group IV) of the fifth instar. Each group previously exposed to pyriproxyfen was divided to three equal sub-groups of 30 larvae. Group I larvae were treated topically with 1, 10, and 100 $\mu \mathrm{g}$ pyriproxyfen/larva in $2 \mu \mathrm{l}$ total volume of acetone using micro-applicator, then fed on clean mulberry leaves until pupation. Group II larvae were fed on mulberry leaves immersed in $1 \%$ glycine for $5 \mathrm{~min}$, then on clean leaves until pupation. Group III larvae were treated with pyriproxyfen as in group I, and then fed on mulberry leaves immersed in glycine as in group II for 1 day, then on clean leaves until pupation. Group IV larvae were treated with pyriproxyfen as in group I in eighth day, then fed on clean leaves until pupation. Group V larvae were treated with only acetone and fed on clean leaves used for comparison as a control group.

\section{Developmental and technological measurements}

Different biological characteristics were measured such as larval weight, larval duration, pupal weight, cocoon weight, cocoon shell weight, and cocoon silk ratio.

For technological measurements, five cocoons of each treatment were dried in an oven at $60{ }^{\circ} \mathrm{C}$ for $8 \mathrm{~h}$ to be reeled individually (Shaaban 1997). The length of reeled silk filament was measured and weighed for each cocoon. The size of the reeled silk filament (denier) was estimated according to Tanaka (1964) formula:

$$
\text { Size }(\mathrm{dn})=\frac{\text { Weight of silk filament }(\mathrm{g})}{\text { Length of filament }(\mathrm{m})} \times 9000
$$

\section{Biochemical determination}

Haemolymph samples were obtained by removing one of the thoracic legs of the fifth instar larvae and bending the body to expose the sternum at the position of the removed leg. This ensured proper drainage of the haemolymph, and avoided any risk of internal organs to be destructed. The haemolymph of each treatment was collected in Eppendorf tubes $1.5 \mathrm{ml}$ containing a few crystals of phenyl-thiourea (PTU) to prevent melanization of samples (Mahmoud 1988). The tubes were kept at -20 ${ }^{\circ} \mathrm{C}$. The blood samples were centrifuged at $10,000 \mathrm{rpm}$ for $10 \mathrm{~min}$ at $5{ }^{\circ} \mathrm{C}$. The supernatant was immediately assayed to determine aspartate transaminase (AST), alanine aminotransferase (ALT) activities according to the method of Reitman and Frankel (1957), total soluble protein (TSP) as described by Gornall et al. (1949), and 
total carbohydrate fractions were determined according to Ishaaya and Swiriski (1976).

\section{Statistical analysis}

The obtained data were subjected to statistical analysis of variance using software COSTAT program and presented as means according to Snedecor and Cochran (1982) methods.

\section{Results}

\section{Biological parameters}

Obtained results on fifth instar larvae of $B$. mori showed that the highest mean weight of mature larvae recorded $5.12 \mathrm{~g}$ when fed on mulberry leaves treated with glycine $1 \%$, whereas it reached $4.82 \mathrm{~g}$ for larvae treated topically by $10 \mu \mathrm{g}$ of pyriproxyfen at eighth day. The results also cleared that the second group treatment (pyriproxyfen and glycine at the fifth day) gave the highest results, especially at concentration of $10 \mu \mathrm{g}$ compared with control and other treatments (Table 1). Statistical analysis revealed that there are significant differences in mature larvae weight for pyriproxyfen concentration and highly significant between treatments.

Topical application of $B$. mori larvae with pyriproxyfen at 1,10 , and $100 \mu \mathrm{g}$ concentrations on eighth day prolonged the duration period of the last instar recording 11.0, 11.0, and 11.5 days, respectively (Table 1 ).
Although, all pyriproxyfen treatment led to prolonged the duration period of fifth instar, unless the best one that treated at fifth day with concentrations of 1 and 10 $\mu \mathrm{g}$ of pyriproxyfen. Statistical analysis revealed high significant differences between larval duration.

The results in Table 1 indicated that all treatments caused highly significant effect on pupal weight of $B$. mori. Treatment of fifth instar larvae with pyriproxyfen at fifth day + glycine $1 \%$ resulted in the highest pupal weight recording 1.277 and $1.273 \mathrm{~g}$ of pyriproxyfen concentration 1 and $10 \mu \mathrm{g}$, respectively. Control larvae attained the lowest mean pupal weight $(0.936 \mathrm{~g})$.

\section{Technological parameters Cocoon characters}

The weight of fresh cocoon was clearly affected by JHA insecticide and glycine amino acid (Table 2). Larvae treated topically with 1 and $10 \mu \mathrm{g}$ pyriproxyfen then fed on mulberry leaves previously treated with glycine amino acid only at $1 \%$ concentration showed highest cocoon weight reaching 1.720 and 1.674 g, respectively. In addition, larvae fed on mulberry leaves treated with glycine amino acid only at $1 \%$ concentration reached $1.640 \mathrm{~g}$. Control larvae represented the lowest cocoon weight recording $0.956 \mathrm{~g}$. The differences among means showed high significance

Table 1 Effect of pyriproxyfen and glycine on different biological parameters of B. mori larvae

\begin{tabular}{|c|c|c|c|c|c|c|}
\hline \multirow[t]{2}{*}{ Treatment } & \multirow[t]{2}{*}{$\operatorname{conc}^{a}$} & \multicolumn{3}{|c|}{ Larval weight (g) } & \multirow{2}{*}{$\begin{array}{l}\text { Larval duration } \\
\text { (day) }\end{array}$} & \multirow{2}{*}{$\begin{array}{l}\text { Pupal weight } \\
\text { (g) }\end{array}$} \\
\hline & & $1^{\text {st }}$ day & $6^{\text {th }}$ day & $\overline{\text { Mature larvae }}$ & & \\
\hline \multirow{3}{*}{$\begin{array}{l}\text { Pyriproxyfen at } \\
2^{\text {nd }} \text { day }\end{array}$} & 1 & 0.823 & 2.876 & 4.46 & 10 & 1.069 \\
\hline & 10 & 0.826 & 2.850 & 4.27 & 10 & 1.213 \\
\hline & 100 & 0.796 & 2.896 & 4.22 & 9.83 & 1.187 \\
\hline Mean & & 0.815 & 2.874 & 4.32 & 9.94 & 1.156 \\
\hline \multirow{3}{*}{$\begin{array}{l}\text { Pyriproxyfen }+ \text { Glycine } \\
1 \% \text { at } 5^{\text {th }} \text { day }\end{array}$} & 1 & 0.816 & 2.916 & 4.38 & 10 & 1.273 \\
\hline & 10 & 0.790 & 3.000 & 4.79 & 10 & 1.277 \\
\hline & 100 & 0.793 & 2.990 & 4.73 & 9.66 & 1.228 \\
\hline Mean & & 0.800 & 2.968 & 4.64 & 9.88 & 1.259 \\
\hline \multirow[t]{3}{*}{ Pyriproxyfen at $8^{\text {th }}$ day } & 1 & 0.793 & 2.69 & 4.36 & 11 & 1.202 \\
\hline & 10 & 0.790 & 3.186 & 4.82 & 11 & 1.267 \\
\hline & 100 & 0.766 & 3.093 & 4.68 & 11.50 & 1.219 \\
\hline Mean & & 0.783 & 2.990 & 4.62 & 11.16 & 1.229 \\
\hline Glycine 1\% & 1 & 0.733 & 3.026 & 5.12 & 9 & 1.001 \\
\hline Control & & 0.753 & 2.933 & 4.74 & 9 & 0.936 \\
\hline L.S.D 0.05 Conc. & & 0.054 & 0.224 & 0.298 & 0.793 & 0.205 \\
\hline$P \geq 0.05$ & & $0.0395^{*}$ & $0.0162^{*}$ & $0.0000^{* * *}$ & $0.0000^{* * *}$ & $0.0026^{* *}$ \\
\hline L.S.D. 0.05 Treatment & & 0.027 & 0.145 & 0.172 & 0.436 & 0.103 \\
\hline$P \geq 0.05$ & & $0.0000^{* * *}$ & $0.0077^{* *}$ & $0.0000^{* * *}$ & $0.0000^{* * *}$ & $0.0000^{* * *}$ \\
\hline
\end{tabular}

$\mathrm{NS}, *$, **, **** denote not significant and significant differences at $0.05,0.01$ and 0.001 levels of probability, respectively

${ }^{a}$ The tested concentrations of pyriproxyfen ( $\mu \mathrm{g} / \mathrm{larva}$ ) and the glycine concentration tested is $1 \%$ 
Table 2 Effect of pyriproxyfen and glycine on technological parameters (cocoon indexes and filament characters)

\begin{tabular}{|c|c|c|c|c|c|c|c|}
\hline \multirow[t]{2}{*}{ Treatment } & \multirow[t]{2}{*}{$\operatorname{conc}^{a}$} & \multicolumn{3}{|c|}{ Cocoon characters } & \multicolumn{3}{|c|}{ Silk filament characters } \\
\hline & & $\begin{array}{l}\text { Cocoon weight } \\
\text { (g) }\end{array}$ & $\begin{array}{l}\text { Cocoon shell weight } \\
\text { (g) }\end{array}$ & $\begin{array}{l}\text { Cocoon silk ratio } \\
(\%)\end{array}$ & $\begin{array}{l}\text { Silk filament length } \\
(\mathrm{m})\end{array}$ & $\begin{array}{l}\text { Silk filament weight } \\
\text { (g) }\end{array}$ & $\begin{array}{l}\text { Silk filament size } \\
(\mathrm{dn})\end{array}$ \\
\hline \multirow{3}{*}{$\begin{array}{l}\text { Pyriproxyfen at } \\
2^{\text {nd }} \text { day }\end{array}$} & 1 & 1.192 & 0.372 & 25.732 & 1091.75 & 0.292 & 2.99 \\
\hline & 10 & 1.192 & 0.291 & 24.381 & 1294.08 & 0.331 & 2.92 \\
\hline & 100 & 1.222 & 0.285 & 23.305 & 1220.75 & 0.300 & 2.79 \\
\hline Mean & & 1.0202 & 0.316 & 24.473 & 1202.19 & 0.308 & 2.91 \\
\hline \multirow{3}{*}{$\begin{array}{l}\text { Pyriproxyfen }+ \text { Glycine } \\
1 \% \text { at } 5^{\text {th }} \text { day }\end{array}$} & 1 & 1.674 & 0.46 & 27.473 & 1523.889 & 0.33 & 2.50 \\
\hline & 10 & 1.720 & 0.497 & 28.897 & 1403.889 & 0.497 & 3.28 \\
\hline & 100 & 1.469 & 0.388 & 26.393 & 1700.111 & 0.377 & 2.52 \\
\hline Mean & & 1.621 & 0.448 & 27.588 & 1542.62 & 0.382 & 2.77 \\
\hline \multirow{3}{*}{$\begin{array}{l}\text { Pyriproxyfen } \\
\text { at } 8^{\text {nd }} \text { day }\end{array}$} & 1 & 1.443 & 0.291 & 24.381 & 1291.83 & 0.304 & 2.64 \\
\hline & 10 & 1.409 & 0.291 & 24.381 & 1421.33 & 0.315 & 2.53 \\
\hline & 100 & 1.441 & 0.405 & 28.048 & 1478.44 & 0.358 & 2.54 \\
\hline Mean & & 1.431 & 0.329 & 25.603 & 1397.20 & 0.325 & 2.58 \\
\hline Glycine 1\% & 1 & 1.640 & 0.460 & 28.057 & 1466.44 & 0.391 & 2.76 \\
\hline Control & & 0.956 & 0.245 & 22.639 & 1226.25 & 0.316 & 2.710 \\
\hline L.S.D 0.05 Conc. & & 0.164 & 0.068 & 2.244 & 270.286 & NS & NS \\
\hline$P \geq 0.05$ & & $0.0000^{* * *}$ & $0.0000^{* * *}$ & $0.0000^{* * *}$ & $0.0079^{* *}$ & 0.4086 & 0.6888 \\
\hline L.S.D 0.05 treatment & & 0.091 & 0.041 & 1.183 & 135.21 & Ns & NS \\
\hline$P \geq 0.05$ & & $0.0000^{* * *}$ & $0.0000^{* * *}$ & $0.0000^{* * *}$ & $0.0000^{* * *}$ & 0.1197 & 0.7307 \\
\hline
\end{tabular}

NS, ${ }^{*}, * * * * *$ denote not significant and significant differences at $0.05,0.01$, and 0.001 levels of probability, respectively

${ }^{a}$ The tested concentrations of pyriproxyfen ( $\left.\mu \mathrm{g} / \mathrm{larva}\right)$ and the glycine concentration tested is $1 \%$

The highest mean of cocoon shell weight recorded $0.497 \mathrm{~g}$ resulted from larvae treated topically with pyriproxyfen at $10 \mu \mathrm{g}$ concentration in combination with glycine $1 \%$ at fifth day of fifth instar larvae. While, the second highest mean weight of cocoon shell weight recording $0.460 \mathrm{~g}$ resulted from larvae fed on mulberry leaves treated with glycine amino acid, in comparison with the lowest one $(0.245 \mathrm{~g})$ recorded for control larvae. Generally, all treatments resulted in an increase in mean weight of cocoon shell. Statistical data analysis revealed highly significant differences for shell cocoons weight means between concentrations and treatments.

Concerning cocoon shell ratio, using pyriproxyfen concentration $10 \mu \mathrm{g}$ in combination with glycine $1 \%$ at fifth day of last instar and pyriproxyfen concentration $100 \mu \mathrm{g}$ at eighth day gave the highest cocoon shell ratio 28.89 , and $28.048 \%$, respectively. While, recorded 28.057 $\%$ when treated mulberry leaves by glycine $1 \%$ only. Control larvae showed the least mean of cocoon shell ratio $(22.639 \%)$.

\section{Silk filament characters}

The length $(\mathrm{m})$, weight $(\mathrm{g})$, and size ( $\mathrm{dn}$ ) of silk filament are given in Table 2. Data obtained revealed that the highest mean silk filament length recorded $1700.11 \mathrm{~m}$ for (second group) pyriproxyfen $(100 \mu \mathrm{g})$ at fifth day and treated mulberry leaves with glycine $1 \%$, followed by $1523.88 \mathrm{~m}$ for pyriproxyfen $(1 \% \mu \mathrm{g})$ for the same treatment. In continuation, the treatment of glycine $1 \%$ only gives $1466.44 \mathrm{~m}$, while the lowest length recorded $1091.75 \mathrm{~m}$ for larvae treated with pyriproxyfen $(1 \mu \mathrm{g})$ at second day. The control attained $1226.25 \mathrm{~m}$. Data analysis cleared that there are highly significant differences between silk filament length means.

With respect to silk filament weight, larvae in the second group (treated topically with pyriproxyfen $10 \mu \mathrm{g}$ and fed on mulberry leaves treated with glycine $1 \%$ ) recorded the highest mean $(0.497 \mathrm{~g})$ at fifth day of fifth larval instar followed by $(0.391 \mathrm{~g})$ for larvae fed on mulberry leaves treated with glycine $1 \%$. Meanwhile, the lowest filament weight $(0.292 \mathrm{~g})$ was recorded with (JHA) pyriproxyfen treatment at second day, regardless the concentration.

Concerning silk filament size, obtained results cleared that the tested compounds did not affect the size of silk filament. The highest mean size ( $3.28 \mathrm{dn}$ ) was noticed by treatment the larvae with pyriproxyfen $(10 \mu \mathrm{g} / \mathrm{larva})$ and glycine $1 \%$ on fifth day of fifth instar larvae.

\section{Physiological measurements}

The used treatment (pyriproxyfen and glycine) affected the physiological studies where the total soluble protein 
decreased for all treatments of pyriproxyfen. Regarding the effect of tested compounds on some physiological parameters, maximum mean value of total protein (78.433 $\mathrm{mg} / \mathrm{ml}$ ) was recorded for control larvae; meanwhile, larvae fed on mulberry leaves treated with glycine amino acid $1 \%$ concentration attained $71.767 \mathrm{mg} / \mathrm{ml}$. Pyriproxyfen caused negative effect on total protein content, showing 23.402, 23.096, and $20.736 \mathrm{mg} / \mathrm{ml}$ for treatments with pyriproxyfen on second day, pyriproxyfen on fifth day + glycine $1 \%$, pyriproxyfen on eighth day, successively, regardless of the concentration (Table 3).

The obtained results showed that the total carbohydrates increase for larvae treated with pyriproxyfen concentration, compared to that treated with glycine and control group. In addition, the values have gradually declined according to the time of application. AST content increased in all treatments than control, recorded 68.473, 64.110, 72.033, 27.094, and $21.434 \mathrm{mg} / \mathrm{ml}$ for pyriproxyfen on second day, pyriproxyfen on fifth day + glycine $1 \%$, pyriproxyfen on eighth day, glycine $1 \%$ and control, respectively, regardless of the concentration. On the other hand, ALT content recorded 9.017, 7.748, $28.031,42.947$, and $51.053 \mathrm{mg} / \mathrm{ml}$ for the respective abovementioned treatments.

\section{Discussion}

Sesquiterpenoid JHs play a crucial role in the development, metamorphosis, and reproduction of insects (Riddiford, 1994). In the current study, effect of JHA, pyriproxyfen, and glycine amino acid on B. mori development and silk production has been investigated in order to give an overview for possibility use to increase the silk production. Results showed increase in larval weight and larval duration due to exposure to pyriproxyfen and glycine. Applying treatment on the fifth day of last instar prolonged larval duration by 1 day considered to be better than treatment at another time (2 and 8 days of larval instar), which gave the best results for biological and technological study. Increasing in larval weight and larval duration might be attributed to the action of pyriproxyfen that mimicking $\mathrm{JH}$ action in larval stage (El-Sheikh et al. 2016) giving the youth characteristics. Accordingly, larvae are still in juvenoid state longer with consuming more food and increase in weight as recorded in the current study. The increase in larval weight and prolongation in larval duration observed in the current study were confirmed in Spodoptera frugiperda larvae when exposed topically into three JHA insecticides (1 $\mu \mathrm{g} /$ larvae) which showed to markedly increase larval duration from 4 to 6 days (El-Sheikh et al. 2016). Also, methoprene and other juvenoide hormone mimics found to positively influence the duration of fifth instar larvae of B. mori (José et al. 2002; Vitthalrao et al. 2015; Kenji 2017; Neog et al. 2017) mentioned that application of $1 \mu \mathrm{g}$ methoprene resulted in significant increase in pupal weight of silkworm, topical application of acetone solution of limonene.

Obtained data cleared that using glycine $1 \%$ alone or with pyriproxyfen concentration led to the highest biological and technological measurements. Increasing in technological parameters (cocoon characters) in the current study are in agreement with those of Babu et al. (1992) who observed an enhancement growth and spinning in the Mysore abd $\mathrm{NB}_{4} \mathrm{D}_{2}$ variety of $B$. mori when

Table 3 Effect of pyriproxyfen and glycine on physiological measurements

\begin{tabular}{|c|c|c|c|c|c|}
\hline \multirow[t]{2}{*}{ Treatment } & \multirow[t]{2}{*}{$\operatorname{conc}^{a}$} & \multicolumn{4}{|c|}{ Physiological measurements } \\
\hline & & Total protein & Total carbohydrate & AST & ALT \\
\hline \multirow{3}{*}{$\begin{array}{l}\text { Pyriproxyfen } \\
\text { at } 2^{\text {nd }} \text { day }\end{array}$} & 1 & 23.321 & 14.211 & 58.433 & 8.993 \\
\hline & 10 & 24.000 & 19.474 & 75.100 & 8.167 \\
\hline & 100 & 22.887 & 14.211 & 71.887 & 9.891 \\
\hline Mean & & 23.402 & 15.965 & 68.473 & 9.017 \\
\hline \multirow{3}{*}{$\begin{array}{l}\text { Pyriproxyfen }+ \text { Glycine } \\
1 \% \text { at } 5^{\text {th }} \text { day }\end{array}$} & 1 & 23.321 & 11.233 & 48.453 & 7.993 \\
\hline & 10 & 22.000 & 12.474 & 73.112 & 6.367 \\
\hline & 100 & 23.887 & 11.440 & 70.767 & 8.884 \\
\hline Mean & & 23.096 & 11.715 & 64.110 & 7.748 \\
\hline \multirow{3}{*}{$\begin{array}{l}\text { Pyriproxyfen } \\
\text { at } 8^{\text {nd }} \text { day }\end{array}$} & 1 & 23.321 & 9.211 & 68.423 & 9.973 \\
\hline & 10 & 20.000 & 10.474 & 77.100 & 8.467 \\
\hline & 100 & 18.887 & 8.211 & 70.577 & 9.591 \\
\hline Mean & & 20.736 & 9.298 & 72.033 & 8.591 \\
\hline Glycine 1\% & 1 & 71.767 & 4.167 & 27.094 & 42.947 \\
\hline Control & & 78.433 & 0.196 & 21.434 & 51.053 \\
\hline
\end{tabular}

${ }^{a}$ The tested concentrations of pyriproxyfen ( $\mu \mathrm{g} / \mathrm{larva}$ ) and the glycine concentration tested is $1 \%$ 
exposed to glycine concentration. In addition, Biswaranjan and Kallyani (2011) evaluated the effect of dietary glycine on growth and production of $B$. mori and found that cocoon weight increased in the majority of the tested groups. Moreover, Saad et al. (2014) observed that the cocoon parameters and economical parameters were enhanced by $0.1 \%$ glycine-treated larvae than control indicating that glycine can act as a good supplement in cocoon production. Regarding the effect of growth regulator, José et al. (2002) and Neog et al. (2017) tested the application of $1 \mu \mathrm{g}$ methoprene and recorded the heaviest weight of $B$. mori cocoon, which is explained by the presence of certain growth stimulant activity that can be used to increase silk yield in commercial silkworm rearing. Obtained results are in conformity with those of Biswaranjan and Kallyani (2011), who stated that 3\% glycine was found to have a magnificent role on increased shell production.

The results of silk filament characters are in connection with those obtained by Vitthalrao et al. (2015) who mentioned that topical application of acetone solution of limonene improved the silk filament and denier. In addition, Kenji (2017) stated that a JH mimic is useful in increasing the yield of silk.

Physiological parameters in the current study revealed, in general, decrease in most of the investigated measurements due to $B$. mori larval exposure to pyriproxyfen and glycine. In the opposite of the finding in the current study, Daojun et al. (2014) found that JHA application significantly increased the protein processing. Bindu et al. (2015) and Leonardi et al. (1996) studied the toxicological effect of chlorantraniliprole on the total haemolymph protein and found that it increased with larval age in the untreated control larvae of $B$. mori; meanwhile, in the treated larvae, the protein level is reduced.

\section{Conclusion}

This study showed that glycine (1\%) alone or in combination with pyriproxyfen $(10 \mu \mathrm{g})$ is the most effective substance compared with high concentration of pyriproxyfen on cocoon characteristics, i.e., cocoon weight, cocoon shell weight, and cocoon silk ratio, that might be beneficial for rearing and producing silk. The fifth day of last silkworm instar is the best time to apply the investigation by pyriproxyfen to apply as JHs, as well as amino acid glycine. Therefore, it can be recommend using glycine alone or with pyriproxyfen $(10 \mu \mathrm{g})$ at last instar of silkworm larvae to improve the silk production. This finding will help the researchers to cover the areas of quality production of silk and food supplementation of $B$. mori diet.

\section{Abbreviations}

ALT: Alanine aminotransferase activities; AST: Aspartate transaminase activities; Dn: Denier (silk filament size measuring unit); IGRs: Insect growth regulators; JHA: Juvenile hormones analogs; JHs: Juvenile hormones; TSP: Total soluble protein

\section{Acknowledgements}

The authors would like to acknowledge sericulture department, Plant proterction Institute, ARC, Egypt for providing silkworm hybrid.

\section{Authors' contributions}

MSIS carried out the breeding and physiological studies, participated in the design of the study, performed the statistical analysis, and helped to revise the manuscript. WMH participated in the sequence alignment and drafted the manuscript, and helped to revise the manuscript. EAE conceived of the study, and participated in its design and coordination and helped to draft the manuscript. All authors read and approved the final manuscript.

\section{Funding}

No funding for this personal research.

\section{Availability of data and materials}

The datasets used and/or analyzed during the current study are available from the corresponding author on reasonable request.

Ethics approval and consent to participate

Not applicable.

\section{Consent for publication}

Not applicable.

\section{Competing interests}

The authors declare that they have no competing interests.

\section{Author details}

${ }^{1}$ Plant Protection Research Institute, Agricultural Research Center, Dokki 12622, Egypt. ${ }^{2}$ Department of Plant Protection, Faculty of Agriculture, Zagazig University, Zagazig 44511, Egypt.

Received: 29 January 2019 Accepted: 14 August 2019

Published online: 05 September 2019

\section{References}

Akai H, Kiguchi K, Kobari Y, Shibukawa A (1971) Practical utilization of juvenoids for increasing silk production. Sci Papers Institute Organic Phys Chem 22: 781-792

Akai H, Kimura K, Kiuchi M, Shibukawa A (1973) Effects of anti-juvenoid treatment on cocoon and cocoon filaments in Bombyx mori L. J Sericultural Sci Japan 55:545-546

Aribi N, Smagghe G, Lakbar S, Soltani-Mazouni N, Soltani N (2006) Effects of pyriproxyfen, a juvenile hormone analog, on development of the mealworm, Tenebrio molitor. Pestic Biochem Physiol 84:55-62

Babu M, Swamy MT, Rao RK, Rao MS (1992) Effect of ascorbic acid enriched mulberry leaves on rearing of Bombyx mori L. Indian J Seric 31(2):111-114

Bindu PU, Priya BKP, Akhilesh VP, Jisha KEK, Rukhsana K, Sebastain CD (2015) Toxicological effect of chlorantraniliprole on fat body and haemolymph metabolism in the final instar larvae of silk insect Bombyx mori L. Int J Sci Nat 6(2):177-182

Biswaranjan P, Kallyani B (2011) Effect of dietary alpha glycine on cocoon production in the silkworm, Bombyx mori L. Curr Trends Biotechnol Pharm 5(2):1157-1162

Cappellozza L, lanne P, Cappellozza S (1997) Effect of body weight on effectiveness of the insect growth regulator (I.G.R.) fenoxycarb applied to the male and female silkworm (Bombyx mori L.) (Lepidoptera: Bombycidae). Sericologia 37:443-452

Chowdhary SK, Raju RS, Ogra RK (1990) Effect of JH analogues on silkworm, Bombyx mori L., growth and development of silk gland. Sericologia. 30:155165

Daojun C, Jian P, Meng M, Ling W, Lixia Kang Wenliang Q, Qingyou X (2014) Microarray analysis of the juvenile hormone responsein larval integument of the silkworm, Bombyx mori. Int J Genom 426025:1-15

El-Sheikh EA, Kamita GS, Hammock BD (2016) Effects of juvenile hormone (JH) analog insecticides on larval development and $\mathrm{JH}$ esterase activity in two spodopterans. Pestic Biochem Physiol 128:30-36 
Gornall AG, Bardawi CD, David MM (1949) Termenation of serumprotein by means of bruit reaction. J Biological Cham 177:751-766

Ishaaya I, Swiriski E (1976) Trehalase, invertase and amylase activities in the black scale, saissetic oleae and their relation to host a daptility. J Insect Physiol 16: 1025-1029

José EM, Sérgio A de B, Roque T (2002) Development and silk production by silkworm larvae after topical application of methoprene. Scientia Agricola 59(3):585-588

Kenji M (2017) New synthesis of astereoisomeric mixture of methyl 12trishomofarnesoate, a juvenile hormone mimic useful in sericulture by increasing silk production. Proc Jpn Acad Ser B 93(93):648-658

Kotikal Y, Devaiah MC (1986) Juvenile hormones in sericulture. Indian Silk 25:19-20

Kremen C, Nijhout HF (1998) Control of pupal commitment in the imaginal discs of Precis coenia (Lepidoptera: Nymphalidae). J Insect Physiol 44:287-298

Krishnaswami S (1978) New technology of silkworm rearing. Central Sericulture Researches and Training. Institute Mysore Bull 2:1-10

Leonardi MG, Cappellozza S, lanne P, Cappellozza L, Parenti P, Giordana B (1996) Effects of the topical application of an insect growth regulator (fenoxycarb) on some physiological parameters in the fifth instar larvae of the silkworm Bombyx mori L. Comp Biochem Physiol 113B:361-365

Mahmoud SM (1988) Activation of silk secretion by silkworms, Philosamia ricini and Bombyx mori L. After applying antibiotics. Ph.D. Thesis, Faculty of Agriculture Cairo University Egypt

Murakoshi S, Chang CF, Tamura S (1972) Increase in silk production by silkworm, Bombyx mori L. due to oral administration of juvenile hormone analogue. Agric Biol Chem 36:695-696

Neog K, Dutta P, Choudhury B, Singh BK (2017) Field efficacy of methoprene, a juvenile hormone analogue, on growth, cocoon characters and fecundity of the muga silkworm Antheraea assamensis Helfer (Lepidoptera: Saturniidae). Int J Agric Policy Res 5(9):115-127

Reitman SMD, Frankel SA (1957) Colorimetric method for the determination of serum glutamic oxaloacetic and glutamic-pyruvic transaminase. Ann J Clin Pathol 28(56):62

Riddiford LM (1994) Cellular and molecular actions of juvenile hormone: genera considerations and premetamorphic actions. Adv Insect Physiol 24:213-274

Saad IAI, Rehab H, Saad MSI (2014) Effect of mulberry leaves enriched with the amino acid glycine on some biological aspects of silkworm, B. mori L. Minufiya J Agri Res 39 2(2):759-764

Saad MSI (2009) Effect of some chemical elements on mulberry silkworm, B. mor L. Ph. D. Thesis. Faculty of Agricultre Benha University Egypt

Shaaban FO (1997) Studies on the silkworm, Bombyx mori L. M.Sc. Thesis. Faculty of Agriculture Zagazig University, p 134

Snedecor GW, Cochran WG (1982) Statistical methods. lowa State Univ. Press, Amer Tanaka Y (1964) Sericology Central Silk Board, Bombay (95). B Megdoot Marine Drive 216-220.

Vitthalrao BK, Vivekanand VK, Randy WS (2015) Utilization of the topical application of limonene to the fifth instar larvae of the silkworm, Bombyx mori (L.) (Race: PM $\times \mathrm{CSR}_{2}$ ) for the parameters of larvae, cocoon and silk filament. Int J Bioassays 4(02):3632-3635

Yang Y, Chen L, Tang Q, Zhang Y, Tang H, Lü P, Yao Q, Chen K (2017) Comparative proteomic analysis reveals that juvenile hormone binding protein and adenylate kinase may be involved in the molting process of silkworm, Bombyx mori. ISJ 14:388-403

Zannoon AA, Omra SM (1994) Efficiency of certain natural materials as mountages for mulberry silkworm, Bombyx mori L. Egypt. J Appl Sci 9(8):691-696

\section{Publisher's Note}

Springer Nature remains neutral with regard to jurisdictional claims in published maps and institutional affiliations.

\section{Submit your manuscript to a SpringerOpen ${ }^{\circ}$ journal and benefit from:}

- Convenient online submission

- Rigorous peer review

- Open access: articles freely available online

- High visibility within the field

- Retaining the copyright to your article

Submit your next manuscript at $\boldsymbol{\nabla}$ springeropen.com 